\title{
Childhood Days in the Poetry of Dragutin Tadijanović
}

\author{
Tonći Lazibat \\ University of Zagreb, Croatia.
}

\begin{abstract}
How to cite this paper: Tonći Lazibat. (2021). Childhood Days in the Poetry of Dragutin Tadijanović. The Educational Review, USA, 5(1), 1-7.

DOI: $10.26855 /$ er.2021.01.001
\end{abstract}

Received: November 28, 2020

Accepted: December 30, 2020

Published: January 14, 2021

Corresponding author: Tonći Lazibat, University of Zagreb, Croatia. Email: tlazibat@efzg.hr

\begin{abstract}
Connoisseurs of Dragutin Tadijanović's poetic expression would agree that Rastušje, as the place of Tadijanović's birth and growing up, inspired the living of his poetry, in particular the theme of childhood. The motive of childhood is visible in several of Tadijanović's collections, but the aim of this paper is to analyze a specific collection of poems-Days of Childhood. Based on the assumption that it is a collection of poems intended for children, two goals of this paper are imposed: (1) to analyze poems in the context of children's literature theory to check whether Tadijanović's poems meet the criteria of children's poetry, and (2) to re-examine outdated conclusions about this collection and to try to present them in a more recent manner, as since the late 1930s until today it has been possible to find a large number of written comments, reviews and works that have reviewed the thematic-motive level of the collection. Combining methods of induction, deduction, description, comparison, analysis and synthesis, this paper seeks to encourage a re-reading of Tadijanovićs collection and its possible positioning within the tissue of Croatian children's literature.
\end{abstract}

\section{Keywords}

Poetry, Dragutin Tadijanović, Days of Childhood, Childhood

\section{Introduction and Research Methodology}

Defining and narrowly defining the term children's literature has always created controversy and partial solutions because no definition has been completely adequate. However, in the practice of Croatian history and theory of children's literature, the one by Crnković is considered the most acceptable: children's literature is literature intended for children, since it includes the terms literature, children, purpose. In one of his earlier editions, Crnković would limit children's age to the interval from the third to the fourteenth year, as Hranjec points out. In addition, three criteria which need to be met in order for a book to be classified in the field of children's literature are often highlighted: (1) the writer consciously wrote it for children; (2) it was published by a children's literature publishing house; (3) in bookstores and libraries it is on the shelves aimed for children. However, Crnković and Težak add that sometimes none of the conditions are met, but over time the book still becomes rated as one that is suitable for children.

The hypothesis of this paper is that Tadijanović's collection of poems Days of Childhood is intended for children, regardless of the fact that it was created as a reflection and remembrance of his own childhood. Considering that we are herewith touching on a narrower part of the mentioned children's literature, i.e. poetry for children, we need to see according to which characteristics we could characterize a poem as the one whose recipient should be —a child. By systematizing these features, we would get a pattern according to which we could analyze Tadijanovićs poems. In order to achieve this first goal, we will single out the features of poetry for children, supporting them with the theoretical schemes of the most famous theorists and historians of children's literature in Croatia. Here we speak of 
Stjepan Hranjec, Milan Crnković and Dubravka Težak, Marijana Hameršak and Dubravka Zima and Ivo Zalar, but also of additional professional and scientific literature.

Tadijanović (1905-2007) wrote his first poems as a 13-year-old (1918), but they were first published four years later (1922) in Omladina (Youth), a magazine for high school students in which he did not use his name but a pseudonym Margan Tadeon. He would sign his name for the first time in 1930 in Književnik (A Literate) and in Hrvatska revija (Croatian Revue). Given this fact about the very rich and long period of his literary work, we are not surprised by the numerous comments and critiques of his Days of childhood over the last eighty years. Using the method of compilation, we will present the considerations of one part of his critics and try to confirm or refute them, and perhaps offer a new interpretation of his collection.

\section{Interpretation and analysis of the Childhood Days collection}

\subsection{Characteristics of children's poetry}

Appearing in the middle of the $19^{\text {th }}$ century, children's literature in Croatia, as well as poetry for children, played the same role as that for adults - to help in the fight to build a national identity, the Croatian language and strengthen the sense of patriotism. Given the focus on "homeland, God and mother", we could say that literature was a politically engaged activity. With the gradual development of children's literature, didacticism was increasingly emphasized, the cause of which we could partly find in teachers who were at the same time writers and poets.

In addition to the original didacticism, children's poems had some other determinants depending on the period in which they were written. Thus, Hranjec recognizes three periods of children's poetry: older, newer and contemporary. A feature of the older one, among other things, is the construction of a children's poem on "metrical-rhythmic and motive determinants of oral lyrics". Poets find motives in everyday life, so the mostly rural spatial complex is spiced with a lesson that is in line with didacticism. However, Zalar will point out that "poetry is one thing, and rhyming lessons are another". The second period, according to Hranjec, occurs at the beginning of the last century and will last until Vitez's Prepelica (Quail) in 1956. He would be marked by poetry about childhood emerging "from the point of view of an adult author", so Hranjec also includes Tadijanović here. The third period relies entirely on the child's psyche and interest.

If we compare Hranjec's Review of the History of Croatian Literature with the claims of Milan Crnković and Dubravka Težak, we notice a coincidence in terms of the influence of oral literature on the beginnings of children's poetry in Croatia. The two of them introduce malešnica (a tiny poem), a poem that is related to children's everyday life, very functional and containing nonsense, nonsenses characteristic of children. Nonsense is what can provoke humor, and Hranjec would point out in Laughter of Children's Literature that "the freshest language in children's literature is without a doubt the one from which radiates serenity, laughter." Apart from these elements, motives are certainly important, as Crnković and Težak state, but they conclude that these are difficult to concretize, given that they change depending on "changing lifestyles, social development, technical conditions, customs and worldviews". Like Hranjec, they usually place the setting of such songs in an idyllic rural landscape.

Hameršak and Zima will, in addition to the already mentioned features of children's poetry, note that theorists and researchers of children's literature tried an interdisciplinary approach in answering the question of what kind of poetry corresponds to children's psyche, but concluded that individual literary work is categorized as children's or non-children's depending whether it is aligned with children's current needs and children's perception. "In other words, in this context, researchers and theorists define the boundaries and features of children's literature by following, in the words of Jože Skok, their own visions of childhood.”

Based on the considerationsabove, we decided to single out and prove the existence of the following features in the poet's collection, namely: (1) motives from the child's everyday life; (2) children's syntactic sentence structure and simplicity; (3) the presence of humor, play, and immediacy; (4) a range of the child's feelings.

\subsection{Results of research and discussion}

The Days of Childhood collection consists of a total of 13 poems, written in 1935 and published in 1936 and 1937, respectively: My Toys; Rain in the Evening; Rainbow Hunting; Ice Wolf; The Girl and I; If I Were a Teacher; Arithmetic Task; Will I Enter the Room Where the Rug Is; I Carry all the Bags and I'm not a Donkey; My Grandmother Blesses the Grain; A Card to the Battlefield; Youth to the Homeland and Today, thirty-fifth. Tadijanović liked to comment on his poetry, so he noted that in his heart he carried images and experiences from his childhood in Rastušje for a long time, but it still took him a while to translate them into verse because "he may have lacked the zeal of memories of those young days". The question arises as to whether its evocation of childhood can be considered 
appropriate for children?

\subsubsection{Motives from the child's everyday life}

The analysis of these poems reveals the poet's need to, from the perspective of a lyrical subject, who is openly equated with the poet, narrate his former growing up everyday life. It has to do with the narrative that makes his poems lyrical-epic. With narrative narration, Tadijanović achieves dynamism, since his poems are not written in bound verse and do not have that kind of rhythm.

By an insight into the everyday life of a former boy from a Slavonian village, it is evident that in his narration and evocation he refers to family members: father (1, 3); grandfather (1); grandmother (1); mother (2). In a later example, he would mention his brother, and the teacher also plays a big role in his boyhood $(4,5,6)$. When he mentions family, the lyrical subject most often comments on them in the context of the division of daily household duties. Although the boy's feelings towards the teacher are not stated in words, from the context $(4,5,6)$ it can be concluded that she was painted in black and white, i.e. presented as negative. In the child's eyes she is a synonym of the power an individual has over the masses (4); she judges and sadistically enjoys punishment (5) and manipulates and exploits her students as labor (6). The character of the teacher in the history of children's literature is more often analyzed in the context of prose works than in poetry. However, we are not surprised by the dedication of even several songs from Days of Childhood to teachers (there were two!), given that school was an important motive of Tadijanovićs children's everyday life.

(1) My father is not at home, I know that. And grandfather / After lunch he sleeps. My grandmother washes the dishesnow. (My Toys, p. 203)

(2) Mom harvests grain. (Rain in the Evening, p. 204.)

(3) My father always takes me with him / In the car when he goes to bring clover / For horses. He mows and carries, / And I knead in the car. (Rainbow Hunting, p. 205)

(4) It's easy for Miss teacher: / (...) She arrives not to let us watch the soldiers. (...) And our teacher, yes! just says from above: / In class! (If I Were a Teacher, p. 208.)

(5) When we complete the account table, / Then we read from the textbook. Then / Miss teacher asks. Who is not able to repeat, / She takes him by the hair above the ear and pulls / Because there it hurts the most... (Will I Enter the Room Where the Rug Is, p. 210)

(6) In ranks we follow her, / By the municipality, in her courtyard: / Whom she loves more, he climbs / On a walnut and shakes, and then picks up, / And others pluck the grass between the bricks, / In front of the house, or nettles by the wall, / In the courtyard... (Will I Enter the Room Where the Rug Is, p. 210)

\subsubsection{Children's syntactic sentence structure and simplicity}

One of the features of children's poetry would be a simple word order in a sentence, the structure of which resembles the narration of a child, where, for example, a sentence consists of a subject and a verb predicate (7). This does not mean that the lyrical subject does not use somewhat more extended structures, but at the content level they are adapted to the child's age and the possibilities of linguistic expression (8, 9, 10, 11, 12, 13, 14, 15).

(7) I don't like to count. (Arithmetic Task, p. 209)

(8) My grandmother washes the dishesnow, / And she loves me very much. (My Toys, p. 203)

(9) A little more, says the grandmother, and I will be / Seven years old. (Rain in the Evening, p. 204)

(10) I'm done faster than Adam. (Arithmetic Task, p. 209)

(11) Reverend has a leg pain... (My Grandmother Blesses the Grain, p. 212)

(12) I carry the cross adorned (My Grandmother Blesses the Grain, p. 212)

(13) God and my grandmother: they love each other very much (My Grandmother Blesses the Grain, p. 212)

(14) Maybe my father is even further than Russia. (Youth to the Homeland, p. 214)

(15) Why won't anyone tell me / Where did they hide it? They must think: he is small / And he could tell (Youth to the Homeland, p. 214)

In addition to syntactic simplicity, there is also disrespect, i.e. deviation from grammatical and orthographic norms in ACardto the Battlefield (16). This interpolated letter differs from Tadijanović's lyrical expression in the remaining poems of the Days of Childhood. However, the boy addresses his father on behalf of his grandmother, so we could attribute this saying to his grandmother's linguistic expression. This letter from the child is also commented on by Kaštelan, who considers it "a reflection of a naive mentality, state of consciousness and psychological data."

(16) We are all, thank God, alive and well,and we wish you the same from dear God and ourheart. This is what our grandmother tells me and tells metoask you whenthe Most Merciful Emperor will let you come to our house and whenthe war will be over. We athome all greet you and Iwillbe waiting for you every day. Grandma always prays to 
God for you and tells us every day that you would com tomorrow. (A Card to the Battlefield, p. 213)

\subsubsection{The presence of humor, play and immediacy}

Literary theorists and historians agree that play, playfulness, but also humor are the most important features in children's poetry. Given that Tadijanović's childhood lasted at the beginning of the $20^{\text {th }}$ century, and this collection was created from the perspective of Tadijanović-child, it can be assumed that his games are far different from today's children play.

Nonetheless, it is important to point out that Tadijanović is truly talking about play, which also was an important part of his childhood everyday life. In the verses he shows his selflessness in the play (17); brings back today's adult readers to their childhood when they sprinkled and jumped on puddles after rain (18); they sneaked in (19) or wanted to convince themselves of the truth of the story that by going under the rainbow boys become girls and vice versa (20). One of the games that the boy fondly remembers is carrying other people's bags (21), but in one of the subchapters we will explain why he especially enjoyed it.

(17) First I will play a little in the yard; (...) When the other children want / To ride a little, I will let them immediately (My toys, p. 203.)

(18) Yellow water flows down the ditches. We played, we sprinkled. (Rainbow Hunting, p. 205)

(19) We sneak secretly, by Glogovica, among the bushes, hidden, breathless. (Rainbow Hunting, p. 205)

(20) "Whoever slips under the rainbow, he will..." - and so on. (...) "(Rainbow Hunting, p. 205)

(21) My favorite thing is when we go home / And when someone shouts: Who will be the donkey? / I then say: Put the bags on me! (I Carry all the Bags and I'm not a Donkey, p. 211)

In addition to the playfulness elements, humor is also important to children. In this sense, we must note that only one such example was found in the opus of a total of 13 analyzed poems. Although we could include it in the subchapter on the everyday life of Tadijanović-child, the lyrical subject still describes his grandfather's vulgar habit with a touch of humor (22).

(22) If we awaken the grandfather, / He will stretch / And surely curse the saint for us. (My Toys, p. 203)

\subsubsection{A range of the child's feelings}

Ultimately, we believe that Tadijanović's Days of Childhood also show the whole range of feelings of that child. We can talk about a sense of responsibility, given that a six-year-old, or soon a seven-year-old boy, is aware that he has to look after his younger brother (23), or he writes homework because he is aware of his obligations though he does not like mathematics.

(23) That's why I have to / To look afterĐuro (that's my brother); / I have to take care of him / Because my mother reaps grain. (Rain in the Evening, p. 204)

(24) I don't like to count. But still, when I see that I have to, / I imagine and write. (Arithmetic Task, p. 209)

The presence of fear is also one of the important feelings we noticed in Tadijanović-child. Describing the everyday life of Đuro Perišin, who used to kill pigeons from an early age, the child expresses pity for animals, but it is accompanied by fear of the dark (25). In Ice Wolf, he is afraid of the sounds of crackling near the frozen Glogovica and runs away without looking back, not wondering if he really should run away (26). However, this is the point—he acts like a child.

(25) I would be sorry to slaughter a pigeon, / And besides, I would be afraid / To climb into the tower, among the pigeons, into the darkness. (Rain in the Evening, p. 204)

(26) My feet / In fear / They ran, / Without looking back, (Ice Wolf, p. 206)

Fear is also associated with first sympathies. At one time, a part of Tadijanović's everyday life was a girl with whom he picked hazelnuts in the forest. Once, after the job was done, he invited her to lie down together in the shade, but then he was afraid of the possibility that the grandmother would find out (27). His idea to peek under the girl's skirt the following day while she was on a mulberry tree was also interrupted by the fear of the grandmother. He would love to look, but what would he say to the grandmother (28)?

(27) Oh, if grandmother found out! (The Girl and I, p. 207)

(28) And the day after, she climbed on a mulberry tree in front of the house. / I wanted to look up / (I was standing just below her), / But I was afraid: / My grandmother could see me / So what would happen then, I think. (The Girl and I, p. 207)

The boy realizes his first sympathies in the poemThe Girl and I, which makes him blush and he is embarrassed because she is also aware of it (29), but later shyness will be less present, so he would like playing with children by carrying their bags, just to be able to also carry Jela's (30). Later,Tadijanović would comment that he could not remember the girl's name, but as he dedicated the collection of poems to theheart of his heart, that is to his girlfriend 
and later his wife Jela, the girl was given this name for the purposes of the poem.

(29) I will not mention the name / What was her name - / The girl I was picking hazels with / In the forest. (...) I was ashamed. / Because why did I have to blush? (The Girl and I, p. 207)

(30) And it's not heavy for me, because I know I'm carrying / Also Jela's bag. For her I could carry thirty-three bags for sure. // But I wouldn't admit to anyone that I carry all the bags / Because of Jela! ... (I carry all my bags and I'm not a donkey, p. 211.)

Curiosity is typical child's feeling, in our examples it is connected with everyday school life. The boy would like to climb the school fence to see the soldiers marching, but the teacher does not allow them to do so, so his sense of curiosity is even more pronounced (31). Also, the teacher is the one who stimulates his curiosity as she reads the Illustrated Paper while the students solve the tasks. He does not know what the term illustrated means, but he wants to find out (32). The third example is also related to the teacher, and in this case it is about her house right in the school space. The poor country boy has never seen a rug, and now he peeps through the window and fantasizes about how gladly he would enter that room. He would respectfully not only take his shoes off, but also wash his feet, just so he could see that rug (33).

(31) Hey, if I was allowed to climb the fence! (If I Were a Teacher, p. 208.)

(32) What could that mean: i-llu-stra-ted? (ArithmeticTask, p. 209.)

(33) Oh, how I / would like Miss to bring me / Only once to her rooms. (...) And the floor is colorful, the floor is greenish. / It's probably a rug on the floor. / I would take off my shoes, quickly, / And wash my feet, quickly, / Just so I don't soil the carpet. (Will I Enter the Room Where the Rug Is, p. 210.)

Ultimately, there is a reflection on war that is not typically childish. However, as Tadijanović lived his childhood before and during the First World War, it is not unusual that the war became a part of his everyday life and thinking. Since he has a very religious grandmother, he wonders why his grandmother did not prevent the war with her prayer - then Dad would not have to join the army. This is a serious topic in which Tadijanović speaks with a chosen vocabulary and simple children's logic from the perspective of a child (34).

(34) Why didn't grandmother pray to God to free us from the army before Dad went to war? (My Grandmother Blesses the Grain, p. 212.)

Tadijanović touches on a more serious reflection on the war in the last poem of the collection, called Today, thirty-fifth. However, the title already indicates the time lag and the position of the lyrical subject in the present of that time, i.e. in 1935, when the poet was 30 years old. For this reason, we cannot consider this poem suitable for children because it is the poet's cry against the perverted, war-torn society in which he lives (35).

(35) Heartis quite in solitude when memories come / But today you should come out / out of loneliness / and shout / Break the box of memories / Run to the crossroads / A murderous clang reaches you / over the spilled water in the fog / Before you can leave / sickle with which you reap / run to crossroads and shout / Let yellow forests hear you / and heavy black fields / and swallows and chimneys / and let be heard by those who constantly sharp / slaughter knives / Let the valleys resound / Let the peaks swing / Run to crossroads in the goldenness of the sun / run / run / shout / smash (Today, thirty-fifth, p. 217)

\section{Previous considerations on Days of Childhood}

As we have already pointed out, Tadijanović's poetry collection has been the subject of numerous criticiques and debates, on a professional or scientific level. It is clear that not every critical review is equally valuable, especially not one that is not scientifically certified. However, the task is to point out some reflections on the poet's collection.

The first comments appear as early as the late 1930s. Thus, Jelenčić would point out that with none of his collections of poems "Tadijanović is as close to everyday life as in this one. In the same year, Frol would say that the poet remembered his childhood with this collection, but that it is characteristic of "many, many childhoods and that these poems are understandable to a wide range of readers.” The critic sees these poems as those written from the boy's perspective, respecting the child's psyche. In support of the claim that the poems would be appropriate for children, he states that they are seen as "simplicism and naivety full of immediate impression, stories connected by inner rhythm, small observations and crisp language", and Bandić emphasizes "innate naivety", visible in the verses and characteristic of the child's psyche.

To a certain extent, Kozarčanin coincides with Frol, since in Tadijanović's childhood he also sees not only the poet's but also someone else's time. He pointed out that the thirteenth poem, unlike the previous "twelve pictures of different children's worries, questions and joys", becomes a protest of a man "because of a poisoned childhood". Slightly pessimistic, yet realistic, Kozarčanin in the 1930s predicted that future generations of children, who were likely to experience the horrors of war, could identify with the song. Turns out he was right. 
Similar conclusions would be drawn by their contemporaries, emphasizing that the poet's childhood is in fact the childhood of each of the readers. However, has there been a change in recent times as we can talk about more serious reviews and histories of literature, and not just shorter reviews? Idrizović (1984), Zalar (1990), Crnković and Težak (2002) and Hranjec (2006) talk about Tadijanovićs Days od Childhood.

Idrizovic would admit that Tadijanović successfully translated his memories into verses in which he speaks in the voice of a boy, not an adult man. That is why he attributes "originality, spontaneity, simplicity" to them and considers them suitable for children. Zalar would point out that the poet did not actually intend his revived world of childhood for children. It was a long time before he was even included in children's poetry, but when that happened, both adults and children embraced his poems. Zalar pointed out that the Days of Childhood have certainly paved the way for modern children's poetry.

Crnković and Težak are aware that the name of the great Croatian poet - Dragutin Tadijanović-is often associated with the issue of distinguishing between children's poetry and poetry that speaks of childhood. In their History of Croatian Children's Literature, they provide an overview of those who consider or do not consider Tadijanović a poet for children. They mention Joža Skok, a Tadijanović fan who supported the introduction of Tadijanović's poems in textbooks, although he was aware that Tadijanović was writing about the childhood. Mentioning Frangeš and Nazor, they point out that they have wisely bypassed the answer to this current issue, and they personally consider him a poet of their own childhood.

Finally, we should mention Hranjec, who is aware of the current issue and opposes those who do not consider Tadijanović a children's poet, claiming that not only in the Days of Childhood but also in the earlier collection The Sun Over the Fieldsthere are verses "that perfectly suit children's reception optics".

\section{Conclusion}

Starting from the hypothesis that Dragutin Tadijanović is a children's poet, regardless of the fact that he is also a poet about his own childhood, we analyzed the poet's opus from 1936, or from 1937-Days of Childhood. We have previously consulted the claims of today's theorists and historians of children's literature in order to create a pattern according to which we would notice the suitability of Tadijanović's poems for children's age. We have highlighted four determinants, although there are definitely more. These are: (1) motives from the child's everyday life; (2) children's syntactic sentence structure and simplicity; (3) the presence of humor, play, and immediacy; and (4) a range of the child's feelings.

Applying the above pattern to thirteen poems, we observed that the first twelve correspond to child psychology while the last was written from the perspective of an adult lyrical subject and the child would probably not be able to understand it due to lack of life experience. In contrast to this poem, the rest describe the typical everyday life of a rural child by the beginning of the $20^{\text {th }}$ century. Childhood days, accompanied by undisguised autobiography, carry memories of family life, the daily division of household duties, the depiction of an idyllic rural landscape, first sympathies, games with peers, school adventures - we would say perhaps even a contemporary everyday life of a child. With his simple saying and the use of a simpler sentence structure, Tadijanović was able to speak in a child's voice and enable the young reader to identify. Although we cannot claim that the collection is dominated by humor, we have proven that it still exists, and the whole range of feelings that a child experiences corresponds to a child's psychology.

However, what makes the collection seem at first glance distant from the children's is the theme of war, present in the last few poems of the cycle. Despite the more serious tone from which it is clear that the boy is aware of the danger he encounters, he still contemplates by the logic of the child, looking at the world in a somewhat naive way, wondering why his grandmother did not prevent the First World War with her prayer. It is a lyric that was primarily created as a memory of his own childhood, but why would this fact exclude Tadijanović as a children's poet if we proved the poems as suitable for children? The only problem could be the generation gap of a hundred years, given that life circumstances have changed and today's children are more exposed to social networks and may not be in constant social contact as they used to be. Our hypothesis could be supported by the universality of themes and motives used by the poet, which could be familiar to every little reader, namely: reflections on school, first sympathies, relationships with family members and obligations. That is why we support the opinion that Tadijanović is not only a poet about childhood but also a children's poet.

\section{References}

Bandić, Miloš I. (1980). Nad oranicama—sunce, in: Dragutin Tadijanović: zbornik radova o pjesniku, edited by Jure Kaštelan et al., Mladost, Zagreb, 1980, pp. 65-76. 
Brešić, Vinko. (2007). Preface, in: Tadijanović, Dragutin, Izabrana djela, edited by Vinko Brešić, Matica hrvatska, Zagreb, 2007, p. 15-29.

Crnković, Milan, Težak, Dubravka. (2002). Povijest hrvatske dječje književnosti: od početaka do 1955. godine, Znanje, Zagreb, 2002.

Dragutin Tadijanović: zbornik radova o pjesniku, edited by Jure Kaštelan et al., Mladost, Zagreb, 1980.

Frol, Ivo, Nova zbirka pjesama Dragutina Tadijanovića, in: Dragutin Tadijanović: zbornik radova o pjesniku, edited by Jure Kaštelan et al., Mladost, Zagreb, 1980, pp. 48-49.

Hameršak, Marijana, Zima, Dubravka. (2015). Uvod u dječju književnost, Leykam international, Zagreb.

Hranjec, Stjepan. (2006). Pregled hrvatske dječje književnosti, Školska knjiga, Zagreb.

Hranjec, Stjepan. (2000). Smijeh dječje književnosti, Tonimir, Varaždinske Toplice.

Idrizović, Muris. (1984). Hrvatska književnost za djecu: Sto godina hrvatske dječje knjige, Nakladni zavod Matice hrvatske, Zagreb.

Jelenčić, Mirko. (1980). Tadijanovićevi Dani djetinjstva, in: Dragutin Tadijanović: zbornik radova o pjesniku, edited by Jure Kaštelan et al., Mladost, Zagreb, 1980, pp. 46-47.

Kaštelan, Jure. (1969). Preface, in: Pet stoljeća hrvatske književnosti, Book 120: Dragutin Tadijanović, Poems, Articles and Feuilletons, Autobiographical Fragments, The Young Years of Lema Kamen, edited by Jure Kaštelan, Zora - Matica hrvatska, Zagreb, 1969, pp. 7-28.

Kaštelan, Jure. (1980). Vizija harmonije: O pjesničkom djelu Dragutina Tadijanovića, in: Dragutin Tadijanović: zbornik radova o pjesniku, edited by Jure Kaštelan et al., Mladost, Zagreb, 1980, pp. 215-229.

Kozarčanin, Ivo. (1980). Dragutin Tadijanović: Dani djetinjstva, in: Dragutin Tadijanović: zbornik radova o pjesniku, edited by Jure Kaštelan et al., Mladost, Zagreb, 1980, pp. 50-55.

Pet stoljeća hrvatske književnosti, Book 120: Dragutin Tadijanović, Pjesme, članci i feljtoni, autobiografski fragmenti, Mlade godine Lema Kamena, priredio Jure Kaštelan, Zora - Matica hrvatska, Zagreb, 1969.

Tadijanović, Dragutin. (2007). Izabrana djela, edited by Vinko Brešić, Matica hrvatska, Zagreb.

Tadijanović, Dragutin. (2005). Sabrane pjesme 1920.-2005., Školska knjiga, Zagreb.

Zalar, Ivo. (1991). Pregled hrvatske dječje poezije, Školska knjiga, Zagreb, 1991. 